Bangladesh Journal of Neuroscience 2012; Vol. 28 (2) : 74-80

\title{
Association of Serum Folic Acid with Ischemic Stroke
}

\author{
HASAN ZAHIDUR RAHMAN ${ }^{1}$, MD. RAFIQUL ISLAM ${ }^{2}$, MONIRUZAMMAN BHUYIAN ${ }^{1}$, MASUD RANA $^{3}$, \\ RASHED IMAM ${ }^{4}$, ABU JAFAR MD SALAUDDIN ${ }^{4}$, KHAIRUL KABIR PATWARY $^{4}$, \\ MUHAMMAD SALAH UDDIN ${ }^{4}$
}

\begin{abstract}
:
Background: Stroke is the third commonest cause of death in developed countries and is responsible for the physical disability of a large population. The study was designed to see the association of serum folic acid with ischemic stroke. It was concluded that the low levels of folic acid are associated with ischemic stroke. Aim and objectives: To evaluate the association of serum folic acid level with ischemic stroke and to measure and compare the serum folic acid level among the cases and control subjects. Material and method: This study was a case-control study which was conducted in the Department of Neurology and Department of Biochemistry of BSMMU, Dhaka, between the period of $1^{\text {st }}$ January 2010 and 31 $1^{\text {st }}$ December 2011 for duration of two years. A total number of 60 patients presented with ischemic stroke and 60 control person were enrolled in this study. All patients of both sexes, aged between 20 years and above presented with ischemic stroke, from 0 day to 1 month that was confirmed by CT scan of head/MRI of brain. Blood sample was collected from the cases and the controls and analyzed at the Dept. of Biochemistry, BSMMU for estimation of serum folic acid, serum homocysteine fasting blood sugar. Fasting lipid profile for cases only. Result: The mean \pm SD of age of the cases was $58.42 \pm$ 11.47 and among the cases 45 (75.0\%) were male and 15 (25.0\%) were female. Among the control male and female were $43(71.7 \%)$ and 17 (28.3\%) respectively. The mean $( \pm S D)$ serum folate level of case and control group was $6.26( \pm 4.06)$ and $8.07( \pm 4.70)$ respectively. Statistically significant differences was observed between case and control group in term of Serum folate $(p<0.05)$. This study showed serum folate level was deficient at the early period of ischemic stroke. Conclusion: Low serum folate concentration is significantly and independently associated with increased risk for ischemic stroke.
\end{abstract}

Introduction:

Stroke is defined by World Health Organization (WHO) as rapidly developing clinical signs of focal (or global) disturbance of cerebral function, with symptoms lasting $24 \mathrm{~h}$ or longer, or leading to death, with no apparent cause other than of non-traumatic vascular origin ${ }^{1}$.Stroke is the third most common cause of death in the developed world after heart disease and cancer, after the age of 40 and is the most common cause of adult physical disability? Prevalence of stroke in Bangladesh is $0.30 \%$, and the ratio of male: female patient's was $3.44: 2.41^{3}$. It poses a major socio-economic challenge in the occupational and neuro-rehabilitational programmes for survivors ${ }^{4}$.

Among numerous risk factors for stroke, only twothirds of all strokes can be attributed to known causal risk factors. One of them is elevated plasma homocysteine concentration resulting from its metabolic enzyme deficiencies or deficiencies of vitamin $\mathrm{B}_{6}, \mathrm{~B}_{12}$ and folic acid ${ }^{1 .}$ Approximately twothirds of the cases of elevated homocysteine have

1. Associate professor. Department of Neurology. BangabandhuSheikh Mujib Medical Unuversity (BSMMU), Dhaka

2. Associate professor. Department of Neurology. BangabandhuSheikh Mujib Medical Unuversity (BSMMU), Dhaka

3. Medical Officer. Department of Neurology. BangabandhuSheikh Mujib Medical University (BSMMU), Dhaka

4. Medical officer, National Institute of Neuroscience, Dhaka. 
been estimated to be due to low or moderate concentrations of these vitamins of which folic acid is considered the most important ${ }^{5}$. A number of epidemiological studies have linked folate deficiency and resultant elevated plasma total homocysteine levels with an increased risk of cardiovascular disease and ischemic stroke ${ }^{6-10}$.

The best-known beneficial action of FA is its homocysteine lowering effect. Being a cofactor in 1-carbon metabolism, folate promotes the remethylation of homocysteine which is reconverted to methionine by methionine synthase and to cystathionine and subsequently to cysteine, which is excreted in the urine or incorporated into glutathionine ${ }^{7}$.Our study were designed to evaluate the association of serum folic acid level with ischemic stroke and to measure and compare the serum folic acid level among the cases and control subjects.

\section{Materials and Methods:}

This was a case-control study carried out in Department of Neurology of BSMMU, Dhaka, from $1^{\text {st }}$ January 2010 and 31 $1^{\text {st }}$ December 2011.

Cases were selected following the inclusion and exclusion criteria-

\section{A. Inclusion Criteria}

1. All patients of ischemic stroke, confirmed by CT scan of head/MRI of brain from 0 day to 1 month.

2. Patients with ischemic stroke of both sexes.

3. Patients with ischemic stroke of 20 years of age \& above.

B. Exclusion Criteria

1. Patients of stroke from haemorrhage, venous thrombosis.

2. Severely ill patients.

3. Patients or attendants unwilling to take part in the study.

4. Those who are taking the following drugsAnti epileptic, Anti metabolitesmethotrexate, Cholestyramine, Penicillamine, OCP, Multivitamins containing Folic Acid.
5. Patients presented with AF, IHD (within 6 weeks of acute stroke), prosthetic heart valve and endocarditis.

Controls were selected following the inclusion and exclusion criteria-

Inclusion criteria

1. Age and sex group matched with the cases.

2. Other than ischemic stroke patient, persons willing to take part in the study.

\section{Exclusion criteria}

1. Those unwilling to take part in the study.

2. Having overt cardiovascular disease

3. Confounders of low serum folic acid level already described earlier.

Data were collected in a structured questionnaire at stroke clinic and neurology ward in BSMMU. Collection of blood sample \& estimation of serum folic acid, homocysteine, fasting blood sugar, lipid profile from the cases and the controls were done at the department of Biochemistry, BSMMU.

\section{Result:}

A total number of 60 patients of ischemic stroke as case and 60 persons as control were enrolled in this study. The results of the present study as follows:

\section{Table-I}

Distribution of the respondents by age $(n=120)$

\begin{tabular}{lccr}
\hline Age & \multicolumn{2}{c}{ Group } & pvalue \\
\cline { 2 - 3 } & Case & Control & \\
\hline $20-29$ & $1(1.7)$ & $3(5.0)$ & \\
$30-39$ & $3(5.0)$ & $4(6.7)$ & \\
$40-49$ & $6(10.0)$ & $10(16.7)$ & \\
$50-59$ & $22(36.7)$ & $20(33.3)$ & \\
$60-69$ & $14(23.3)$ & $11(18.3)$ & \\
70 and above & $14(23.3)$ & $12(20.0)$ & \\
Total & $60(100.0)$ & $60(100.0)$ & \\
Mean \pm SD & $58.42 \pm 11.47$ & $54.17 \pm 13.97$ & $0.071^{*}$ \\
\hline
\end{tabular}

${ }^{*} t$ test was done to measure the level of significance.

\#Figure within parentheses indicates in percentage

Table 1, shows the distribution of the respondents by age. Mean \pm SD of age of the cases was 58.42 
\pm 11.47 years. Among the cases most common age group was 50 to 59 years (36.7\%) followed by 60 to 69 and 70 and above (23.3\%). Mean \pm SD of age of the control was $54.17 \pm 13.97$ years. Among the control most common age group was 50 to 59 years (33.3\%) followed by in the age group of 70 years and above (20.0\%). There is statistically no significant difference in age between the case and control $(p>0.05)$.

\section{Table-II}

Distribution of the respondents by sex $(n=120)$

\begin{tabular}{lccc}
\hline Sex & \multicolumn{2}{c}{ Group } & pvalue \\
\cline { 2 - 3 } & Case & Control & \\
\hline Male & $45(75.0)^{\#}$ & $43(71.7)$ & $0.680^{*}$ \\
Female & $15(25.0)$ & $17(28.3)$ & \\
\hline Total & $60(100.0)$ & $60(100.0)$ & \\
\hline
\end{tabular}

${ }^{*}$ Chi-square test was done to measure the level of significance. \#Figure within parentheses indicates in percentage.

Table II, shows the distribution of the respondents by sex. Among the cases $45(75.0 \%)$ were male and 15 (25.0\%) were female. Among the control male and female were 43 (71.7\%) and 17 (28.3\%) respectively. There is no statistically significant $(p>0.05)$ difference in sex between the case and control.

Table-III

Distribution of the respondents by history of smoking $(n=120)$

\begin{tabular}{lccl}
\hline History of smoking & \multicolumn{2}{c}{ Group } & p value \\
\cline { 2 - 3 } & Case & Control & \\
\hline Present & $40(66.7)^{\#}$ & $19(31.7)$ & $0.001^{*}$ \\
Absent & $20(33.3)$ & $41(68.3)$ & \\
Total & $60(100.0)$ & $60(100.0)$ & \\
\hline If yes, pack year & & & \\
\hline Mean \pm SD & $4.90 \pm 2.28$ & $3.88 \pm 1.32$ & \\
(Min -Max) & $(2-10)$ & $(2-6)$ & \\
\hline
\end{tabular}

${ }^{*}$ Chi-square test was done to measure the level of significance. \#Figure within parentheses indicates in percentage.

Odd ratio $(95 \% \mathrm{Cl})=4.32(2.01-9.27)$

Table III, shows the distribution of the respondents by history of smoking. Among the cases 40 (66.7\%) were smoker and 20 (33.3\%) were non smoker. Among the control 19 (31.7\%) were smoker and
41(68.3\%) were non smoker. Mean \pm SD of pack year among case and control was $4.90 \pm 2.28$ and $3.88 \pm 1.32$ respectively. There is statistically significant difference in history of smoking between the case and control $(p<0.05)$.

\section{Table-IV}

Distribution of the respondents by hypertension $(n=120)$

\begin{tabular}{lccc}
\hline Hypertension & \multicolumn{2}{c}{ Group } & p value \\
\cline { 2 - 3 } & Case & Control & \\
\hline Present & $48(80.0)^{\#}$ & $07(11.7)$ & $0.001^{*}$ \\
Absent & $12(20.0)$ & $53(88.3)$ & \\
\hline Total & $60(100.0)$ & $60(100.0)$ & \\
\hline
\end{tabular}

*Chi-square test was done to measure the level of significance. \#Figure within parentheses indicates in percentage.

Odd ratio $(95 \% \mathrm{Cl})=30.28(11.02-83.207)$

Table IV shows the distribution of the respondents by hypertension. Among the cases 48(80.0\%) were hypertensive and $12(20.0 \%)$ had normal blood pressure. Among the control 7(11.7\%) were hypertensive and 53(88.3\%) were normotensive. There is statistically significant difference in hypertension prevalence between the case and control $(p<0.05)$.

Table-V

Distribution of the respondents by Diabetes Mellitus $(n=120)$

\begin{tabular}{lccc}
\hline Diabetes Mellitus & \multicolumn{2}{c}{ Group } & p value \\
\cline { 2 - 3 } & Case & Control & \\
\hline Present & $02(03.3)^{\#}$ & $02(03.3)$ & $1.000^{*}$ \\
Absent & $58(96.7)$ & $58(96.7)$ & \\
\hline Total & $60(100.0)$ & $60(100.0)$ & \\
\hline
\end{tabular}

${ }^{*}$ Chi-square test was done to measure the level of significance. ${ }^{\#}$ Figure within parentheses indicates in percentage.

Odd ratio $(95 \% \mathrm{Cl})=1.00(0.14-7.34)$

Table $\mathrm{V}$, shows the distribution of the respondents by diabetes mellitus. Among the cases 2 (3.3\%) were diabetic and 58 (96.7\%) were non diabetic. Among the control 2 (3.3\%) were diabetic and 58 $(96.7 \%)$ were non diabetic. There is statistically no significant difference in diabetes prevalence between the case and control ( $p>0.05)$. 
Table-VI

Serum folate and homocystein level among cases $(n=60)$ and controls $(n=60)$

\begin{tabular}{lccc}
\hline Laboratory findings & \multicolumn{2}{c}{ Group } & p value* \\
\cline { 2 - 3 } & Case & Control & \\
\hline Serum folate $(\mathrm{ng} / \mathrm{ml})$ & $6.26 \pm 4.06$ & $8.07 \pm 4.70$ & 0.025 \\
& $(1.83-18.98)$ & $(1.20-20.98)$ & \\
Serum homocysteine $(\mu \mathrm{mol} / \mathrm{L})$ & $19.05 \pm 11.60$ & & 0.422 \\
& $(5.71-59.00)$ & $(5.71-50.00)$ & \\
\hline
\end{tabular}

*t test was done to calculate the level of significance.

Table $\mathrm{VI}$, shows mean $( \pm \mathrm{SD}$ ) serum folate level of case and control group was $6.26( \pm 4.06)$ and 8.07 $( \pm 4.70)$ respectively. Statistically significant differences of serum folate level was observed between case and control group $(p<0.05)$. Mean $( \pm S D)$ Serum homocysteine level of case and control group was 19.05( \pm 11.60$)$ and $17.46( \pm 9.94)$ respectively. Serum homocysteine level did not show statistically significant differences $(p>0.05)$ between case and control group.

\section{Discussion:}

Age is the single most important risk factor for stroke. In this study the mean \pm SD of age of the cases was $58.42 \pm 11.47$ years, minimum 28 and maximum 80 years. Most common age group of cases was 50 to 59 years (36.7\%) followed by 60 to 69 and 70 and above (23.3\%). Maximum patients of this study were above 46 years. In 1990 Biller J et $a^{11}$ studied 51 stroke patients majority of them being in the 50-69 age groups. Other age group of cases was $40-49$ years (10.0\%), 30 to 39 years (5.0\%) and $20-29$ years (1.7\%). Mean \pm SD of age of the control was $54.17 \pm 13.97$ years with median (52.50) and maximum 86 and minimum 21 years. Among the control most common age group was 50 to 59 years (33.3\%) followed by in the age group of 70 years and above (20.0\%). Other age group in control were 20 to 29 years (5.0\%). 30 to 39 years (6.7\%), 40 to 49 years (16.7\%), 60 to 69 (18.3\%) years. There was statistically no significant difference in age between the case and control $(p>0.05)$ (Table 1). The older the person is, the greater the risk for stroke ${ }^{12}$. For each successive 10 years after age 55, the stroke rate rises more than doubles in both men and women ${ }^{13}$. Present

study revealed that middle and old age people are prone to stroke than the younger group. American Heart Association (AHA) revealed the same fact on 2006 that the older are at the greater risk for stroke $^{12}$. In 2000 Basharat et al. showed that the mean age was 53.0 years for all cases of stroke while mean age in males and females was 56.2 and 48.9 years respectively ${ }^{14}$. This study also shows that the incidence of stroke rises with the increase of age. Similar observation were obtained by Hayee et al. ${ }^{12}$, Banford et al. ${ }^{15}$ and Arif et al. ${ }^{16}$.

Among the cases 45 (75.0\%) were male and 15 (25.0\%) were female. Among the control male and female were $43(71.7 \%)$ and $17(28.3 \%)$ respectively. There is no statistically significant difference in sex between the case and control ( $p>0.05$ ) (Table 2). In 1998 Feigin et al. and Basharat et al. in 2000 found that male was attacked by stroke more than female ${ }^{14,17}$. In Bangladesh, few hospital based studies revealed the male dominant picture $12,18,19$. But Cull et al (1995) concluded that in underdeveloped countries females are given less priority in all respect including hospital admission and treatment for illness ${ }^{20}$.

Among the cases 40 (66.7\%) were smoker and 20 (33.3\%) were non smoker. Among the control 19 (31.7\%) were smoker and 41(68.3\%) were non smoker. Mean \pm SD of pack year among case and control was $4.90 \pm 2.28$ and $3.88 \pm 1.32$ respectively. There is statistically significant difference in history of smoking between the case and control $(p<0.05)$. In one study Jalal Uddin in 2007 found smokers having a risk of ischaemic stroke 1.084 times higher than those of nonsmokers $^{21}$. Somay et al. obtained similar result in 
their study ${ }^{22}$. In a case-control study Khan, found that $55 \%$ of ischaemic stroke patients were smoker where only $33 \%$ were smoker in control group ${ }^{19}$.

Among the cases $48(80.0 \%)$ were hypertensive and $12(20.0 \%)$ were not. Among the control $7(11.7 \%)$ were hypertensive and 53(88.3\%) were not. There is statistically significant difference in hypertension between the case and control $(p<0.05)$. Higher prevalence of hypertension in ischaemic stroke patients was also observed by Somay et $\mathrm{al}^{22}$. Similar results were obtained by Jalal Uddin, Hannan and Khan 18,19,21. In analysis of risk factors of stroke Carrieri noted hypertension was present in $52.11 \%$ of stroke patients ${ }^{23}$. All these findings are consistent with the result of the present study.

Among the cases 2 (3.3\%) were diabetic and 58 $(96.7 \%)$ were non diabetic. Among the control 2 (3.3\%) were diabetic and $58(96.7 \%)$ were non diabetic which showed no significant difference between the case and control $(p>0.05)$. Earlier case-control study found $33 \%$ of the ischemic stroke patient had diabetes while $13 \%$ of the controls were diabetic and diabetes was established as a risk factor for ischemic stroke. The findings of present study are inconsistent with previous studies as this is a hospital base study.

In 1995 Giles et al.noted that folate concentration $\leq 9.2 \mathrm{nmol} / \mathrm{L}$ may be a risk factor for ischemic stroke especially in blacks ${ }^{24}$. Increased folate intake is associated with decreased risk of ischemic stroke in men ${ }^{25}$. But in other studies inconsistency was noted with serum folate or folate intake in relation to incidence of stroke $26-28$.

Mean $( \pm S D)$ serum folate level of case and control group were $6.26( \pm 4.06)$ and $8.07( \pm 4.70)$ respectively which showed significant differences between case and control group $(p<0.05)$. Mean $( \pm S D)$ serum homocysteine level of case and control group were $19.05( \pm 11.60)$ and $17.46( \pm 9.94)$ respectively and did not show statistically significant differences between case and control group ( $p>0.05)$. Homocysteine levels depend in part on folate status, lower folate levels lead to higher homocysteine levels ${ }^{29}$. As a result of the observed inverse association between homocysteine levels and stroke, folate has been hypothesized to be protective against stroke incidence $^{30}$. Folate is required for the remethylation of homocysteine to methionine, which in turn reduces the concentration of homocysteine available to support oxidative stress. Giles et al (1995) investigated whether a folate concentration $\leq 9.2 \mathrm{nmol} / \mathrm{L}$ was associated with ischemic stroke in a national cohort. They noticed that after adjusting for age, race, sex, education, diabetes, history of heart disease, systolic blood pressure, body mass index, hemoglobin level, cigarette smoking, and alcohol intake, participants with a folate concentration $\leq 9.2 \mathrm{nmol} / \mathrm{L}$ were at slightly increased risk for ischemic stroke (relative risk [RR], 1.37; 95\% confidence interval [Cl], 0.82 to 2.29$)^{24}$. There was a folate-race interaction ( $P=.11$ for interaction term). Whites with a folate concentration $\leq 9.2 \mathrm{nmol} / \mathrm{L}$ had a relative risk of $1.18(95 \% \mathrm{Cl}, 0.67$ to 2.08$)$, whereas blacks had a relative risk of $3.60(95 \% \mathrm{Cl}, 1.02$ to 12.71). In 2010 Kirtania et al in a case control study showed that the mean folic acid levels in case group and control group were $2.29 \pm 0.54 \mathrm{ng} / \mathrm{ml}$ and $7.24 \pm 2.19 \mathrm{ng} / \mathrm{ml}$ respectively. They suggested that low levels of serum vitamin $B_{12}$ and folic acid are associated with ischaemic stroke ${ }^{31}$.

\section{Conclusion:}

Low serum folate concentration is significantly and independently associated with increased risk for ischemic stroke. Serum homocysteine concentration appears insignificant as risk for ischemic stroke. Further studies are required to establish these associations in our ethnic population. As the present study conducted in a single center in Dhaka city with small sample size, to find out such potential risk factors, more study is needed to establish that the low serum folate as a risk for ischemic stroke in Bangladeshi population.

\section{References:}

1. WHO Collaborative Study of Cardiovascular Disease and Steroid Hormone Contraception. (1996). Haemorrhagic stroke, overall stroke risk and combined oral contraceptives; results of an international, multi centre, casecontrolled study. Lancet, 348, 505-10.

2. Ropper $\mathrm{AH}$ and Brown $\mathrm{RH}$. Cerebrovascular Diseases. Adams and Victor's Principles of Neurology, 8th (edn), 2005, McGraw-Hill, pp. 661-740. 
3. Islam MN, Moniruzzaman M, Khalil MI, et al. Burden of stroke in Bangladesh. Int J Stroke. 2013; 8(3):211-3.

4. Whisnat, JP. 'Modeling of risk factors for ischaemic stroke : the Willis lecture' Stroke 1997;28:1840-43.

5. Selhub J, Jacques PF, Wilson PWF, Rush $\mathrm{D}$, Rosenberg $\mathrm{IH}$. Vitamin status and intake as primary determinants of homocysteinemia in an elderly population. JAMA 1993;270:2693-98.

6. Ubbrink JB, Vermaak WJH, van der Merve A, Becker PJ, Delport R \& Potgieter HC Vitamin requirements for the treatment of hyperhomocysteinemia in humans. J. Nutr. 1994;124:1927-33.

7. Robinson K, Arheart K, Refsum H, BrattstroÈm L, Boers G, Heland P, et al. for the European COMAC group. Low circulating folate and vitamin B6 concentrations. Risk factors for stroke, peripheral vascular disease, and coronary artery disease. Circulation. 1998;97:437-43.

8. Folsom AR, Nieto FJ, McGovern PG, Tsai NY, Malinow MR, Eckleldt JH, et al: Prospective study of coronary heart disease incidence in relation to total homocysteine, related genetic polymorphism, and B vitamins. Circulation. 1998;98:204-10.

9. Mattson MP, Shear TB. Folate and homocysteine metabolism in neural plasticity and neurodegenerative disorders. Trends Neurosci. 2003;26:137-46.

10. Biller J, Love BB, 2004, 'Ischemic cerebrovascular disease', In WG Bradley,RB Darott, GM Fenichel, J Jankovic (eds.) Neurology in Clinical Practice, 4th edn, Butterworth Heinemann, pp.1197-245.

12. MA. Hayee, Haque A, Anwarullah AKM, Hoque Azharul, Akhter N. Analysis of risk factors in 472 cases. Bangladesh Journal of Neuroscience 1998;14(2):41-54.

13. Sacco RL, Benjamin EJ., Broderick JP, Dyken Mark, Easton JD, Feinberg WM. 1997, 'Risk Factors', Stroke, 28; 1507-17.
14. Basharat RA, Yousuf M, Iqbal J, Khan MM. Frequency of known risk factors for stroke in poor patients admitted to Lahore general hospital in 2000. Pak J Med Sci. 2002;18(4):280-83

15. Banford J, Sandercock P, Dennis M . 'A prospective study of acute cerebrovascular disease in a community: the oxfordshire community stroke project. 1981-86. 1. methodology demography and incident case of first-ever stroke', J-Neural Neurosurg phych 1988;51:1373-80.

16. Arif SM, Khan MZ, Khan NI, Mohammad QD. 'Relation of hypertension with stroke- A study of 100 cases', Bangladesh Journal of Neuroscience 2003; 19: (2): 59-64.

17. Feigin VL, Wiebers DO, Nikitin YP, O'Fallon WM, Whisnant JP. Risk Factors for Ischemic Stroke in a Russian Community: A Population -Based Case-Control Study. Stroke 1998;29:34-9.

18. Hannan MA, 1999, 'Study of seasonal variation of stroke',[Thesis]. Dhaka: Bangabandhu Sheikh Mujib Medical University.

19. Khan MRK, 2000, 'Relationship between blood lipids, lipoproteins and ischaemic stroke',[Thesis]. Dhaka, Bangabandhu Sheikh Mujib Medical University.

20. Cull RE \& Will RG 1995, 'Disease of the nervous system. In: Davidsons Principles and practice of medicine', 16th edn. Hong Kong: ELBS with Churchill Livingstone, pp-1071-79.

21. Jalal Uddin M, 2007, 'Association of lipid profile with ischaemic stroke', [Thesis]. Dhaka,University of Dhaka.

22. Somay G,Aliskan T, Erenglu NY. 'Carotid artery stenosis and Homocystine in ischaemic stroke; A case-control study', Journal of Neurological science (Turkis) 2005; 22: 395-402.

23. Carrieri PB, Orefice G, Maiorino A, Provitera V, Balzano G, Lucariello A. 'Age-related risk factors for ischemic stroke in Italian men', Neuroepidemiology, 1994;13:28-33. 
24. Giles WH, Kittner SJ, Anda RF, Croft JB, Casper ML. Serum folate and risk for ischemic stroke. First National Health and Nutrition Examination Survey epidemiologic follow-up study. Stroke. 1995;26(7):1166-70

25. He K, Merchant A, Rimm EB, Rosner BA, Stampfer MJ,et al. Folate, Vitamin B6, and B12 Intakes in Relation to Risk of Stroke Among Men. Stroke. 2004;35:169-74.

26. Zeitlin A, Frishman $\mathrm{WH}$, Chang $\mathrm{CJ}$. The association of vitamin B 12 and folate blood levels with mortality and cardiovascular morbidity incidence in the old: the Bronx Aging Study. Am J Ther. 1997;4:275-81.

27. Bazzano LA, He J, Ogden LG, Loria C, Vupputuri S, Myers L, et al. Dietary intake of folate and risk of stroke in US men and women: NHANES I Epidemiologic Follow-up Study.
National Health and Nutrition Examination Survey. Stroke. 2002;33:1183-88.

28. Maxwell CJ, Hogan DB, Elby EM. Serum folate levels and subsequent adverse cerebrovascular outcomes in elderly persons. Dement Geriatr Cogn Disord. 2002;13: 225-34.

29. Kang SS, Wong PW, Norusis $M$. Homocystinemia due to folate deficiency. Metabolism. 1987;36:458-62.

30. Swain RA, St Clair L. The role of folic acid in deficiency states and prevention of disease. J Fam Pract. 1997;44:138-44.

31. Kirtania K, Ahmed S, Sultana N, Hossain MZ, Rahman MM. Study on Serum Vitamin B12 And Folic Acid in Patients of Ischaemic Stroke. J Dhaka Med Coll. 2010; 19(2):115-17. 